\title{
OCORRÊNCIA DE DOMÁCIAS EM ESPÉCIES E HÍBRIDOS DA FAMÍLIA VITACEAE *
}

\author{
Myrtes A. AdAmolin DE Barros **
}

\section{RESUMO}

Em prosseguimento ao plano elaborado para o conhecimento da ocorrência das domácias em espécies e híbridos da família Vitaceae, apresentamos os estudos feitos em 43 novas variedades híbridas IAC.

Deste total, 24 apresentaram domácias que se enquadram no tipo "em tufo de pêlos" e variações, segundo a classificação de CHEVALIER \& CHESNAIS (1941).

O material examinado constou de folhas não herborizadas oriundas do Instituto Agronômico de Campinas - Seção de Viticultura.

As folhas apresentavam-se em várias fases de seu desenvolvimento, tendo sido examinadas nas faces ventral e dorsal, na confluência do limbo com o pecíolo, anotando-se as particularidades relativas às domácias tais como: aspecto, localização, tamanho, forma, coloração e tamanho dos pêlos, etc.

Pudemos observar novamente uma pequena variação nas domácias do tipo "em tufo de pêlos" que ora aparecem como "pêlos esparsos", ora como "aglomerado de pêlos" e ainda como "tufo de pêlos" propriamente dito.

As domácias encontradas nos 24 híbridos, estão assim distribuídas :

a) domácias em "tufo de pêlos" e suas variações - 23

b) domácias "em bolsas" - 1

Observamos variações no tamanho e cor dos pêlos, podendo ser claros ou escuros, brancos ou esverdeados, curtos ou longos, lisos ou crespos.

As domácias situam-se na face inferior do limbo, na junção das nervuras com o pecíolo e na axila das nervuras de primeira e segunda ordem.

\section{INTRODUÇÃO}

Neste trabalho, o quinto de uma série, segundo plano elaborado anteriormente (ADAMOLI DE BARROS, 1963) onde reunimos os resul-

* Entregue para publicação em 16/12/1976.

* Prof.a Assistente Doutor do Dept.o de Botânica da ESALQ. 
tados das observações feitas sobre as domácias que ocorrem na família Vitaceae. Servimo-nos para isso da coleção de híbridos cultivados na Seção de Viticultura do Instituto Agronômico de Campinas.

\section{Relação dos novos híbridos estudados}

De acordo com o material recebido do Instituto Agronômico de Campinas - Seção de Viticultura, os híbridos estudados foram os seguintes:

\begin{tabular}{|c|c|}
\hline & 16 \\
\hline & $21-$ \\
\hline & $23-$ \\
\hline & $23-$ \\
\hline & $32-$ \\
\hline & $73-$ \\
\hline & $74-$ \\
\hline & $82-$ \\
\hline & 121 \\
\hline & 12 \\
\hline & \\
\hline
\end{tabular}

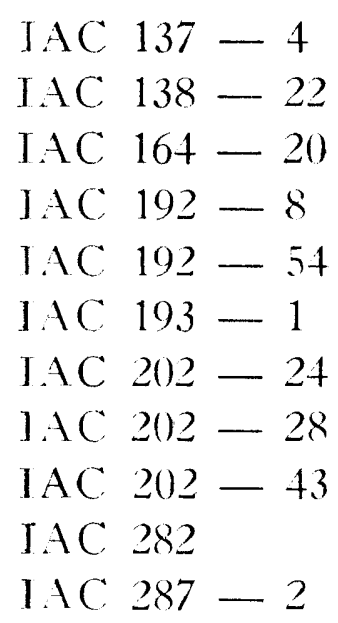

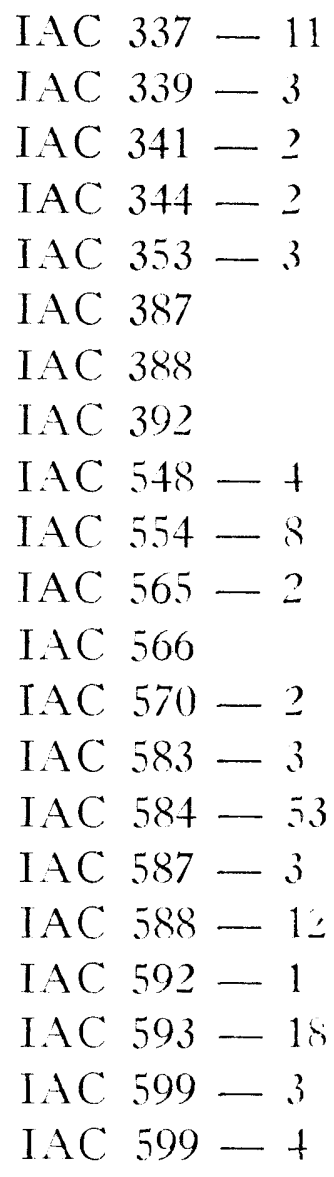

Pela classificação de CHEVALIER \& CHESNAIS (1941) os 24 híbridos portadores de domácias enquadram-se nos seguintes tipos:

A - Domácias em "bolsas"

IAC $202-24$

B - Domácias em "tufo de pêlos"

$\begin{array}{llll}\text { IAC } 16-2 & \text { IAC } 353-3 & \text { IAC } 599-4 \\ \text { IAC } 82-1 & \text { IAC } 388 & \\ \text { IAC } 192-8 & \text { IAC } 392 & \\ \text { IAC } 202-43 & \text { IAC } 548-4 & \end{array}$


Variações deste tipo

a) Domácias em "pêlos esparsos"
IAC $124-11$
IAC $138-22$
IAC 287 - 2
IAC $133-3$
IAC $192-54$
IAC $337-11$
IAC $137-4$
IAC $202-28$
IAC $193-1$
IAC $584-3$

b) Domácias em "aglomerado de pêlos"

IAC $121-58 \quad$ IAC $554-8$

IAC 387

c) Domácias na confluência das nervuras com o pecíolo.

IAC $23-2$

\section{RESULTADOS}

De um total de 43 híbridos examinados, encontramos domácias nas folhas de 24 deles.

As domácias se apresentam na face inferior da folha, ora na axila das nervuras, ora na confluência das nervuras com a inserção do pecíolo.

Observamos a ocorrência dos tipos em "tufo de pêlos" e "em bolsas" da classificação de CHEVALIER \& CHESNAIS (1941).

Nas domácias em "tufo de pêlos", algumas mostraram-se como "pêlos esparsos", "aglomerado de pêlos" e "tufo de pêlos" propriamente ditos.

Pudemos assinalar a presença de ácaros brancos nas imediações e no interior das domácias.

\section{SUMMARY}

This paper deals with the ocurrence of domatia in leaves of hybrids of Vitaceae family. The authorfound dommatia in 24 of 43 hybrids studied.

The domatia found were of the types: in "touffe de poils" and in "pochette", types according to the CHEVALIER \& CHESNAIS (1941).

The leaves were examined in both sides and in the junction of the blade with the petiole.

This paper is the third about this subject. 


\section{LITERATURA CITADA}

ADAMOLI DE BARROS, Myrthes Apparecida, 1963 - I Ocorrência de domácias en espécies e híbridos da família Vitaceae. Anais da E.S.A. "Luiz de Queiroz", vol. XX, pp. 241-255.

ADAMOLI DE BARROS, Myrthes Apparecida, 1966 - II Ocorrência de domácias en espécies e híbridos da família Vitaceae. Anais da E.S.A. "Luiz de Queiroz", vol. XXIII, pp. $10-14$.

ADAMOLI DE BARROS, Myrthes Apparecida, 1968 - III Ocorrência de domácias en espécies e híbridos da família Vitaceae. Anais da E.S.A. "Luiz de Queiroz", vol. XXV, pp. $17-20$.

ADAMOLI DE BARROS, Myrthes Apparecida, 1975 - IV Ocorrência de domácias cm espécies e híbridos da família Vitaceae. Anais da E.S.A. "Luiz de Queiroz", vol. XXXII.

CHEVALIER, AUGUSTE \& FRANCIS CHESNAIS, 1941 - Botanique Sur les domaties. de feuilles de Juglandaceaes. Extraído de C.R. Academic des Sciencies 213 - pp. 389-392. 